\title{
Calcium and Iron Rich Recipes of Finger millet
}

\author{
Tahsin Kazi ${ }^{1}$ * ${ }^{\text {Sanjay Gajanan }}$ Auti $^{2}$ \\ ${ }^{I}$ (Department of botany, H.P.T. Arts and R.Y.K. Science College,Nashik-422005. (M.S.), India) \\ ${ }^{2}$ (Department of botany, H.P.T. Arts and R.Y.K. Science College,Nashik-422005. (M.S.), India) \\ Corresponding author: autisanjay66@gmail.com
}

\begin{abstract}
The Malnutrition is a serious matter of concern among the population of various countries, due to modern lifestyle specifically consumption of rapidly processed fast food. The present situation demands development of products that are rich in mineral nutrients, meet requirement of growth and development and readily acceptable. In this scenario, Finger millet is preferred as foremost choice for required minerals and low calorie diet. In the present work, 64 landraces were collected from Western Ghats of Maharashtra. The collected landraces were analyzed for their mineral contents. The 12 best landraces containing higher amount of minerals, especially calcium and iron were selected for recipes preparation. Seven recipes of finger millet namely Cookies, Idli, Dosa, Laddu, Cake, papad and Sheera were standardized. Standardized recipes and marketed finger millet products namely cookies, papad and biscuits were analyzed for minerals, calcium and iron by using ICP OES. (AOAC 2011.14). Among recipes, cookies retain a good amount of calcium (194.8mg/100gm) and iron (257.49 $\mathrm{mg} / \mathrm{kg})$, while Laddu (194.3mg/100gm) and Cake (123.5mg/100gram) retains maximum amount of calcium. The comparative analysis between marketed and standardized recipes reveal that the standardized recipes contain more amount of calcium and iron and consumer acceptability index was carried out by using standard organoleptic test. It was found to be more than $80 \%$ for all the recipes. Present work will provide calcium and iron rich recipes to customize finger millet as nutritional crop and enhances the awareness towards marketed products.
\end{abstract}

Keywords: Finger millet, standardization of recipes, minerals analysis, organoleptic test.

\section{Introduction}

In past few years, the consumption of fast foods resulted in reduced intake of dietary fibres and other micronutrients as a result of urbanized life style, changes in practices and level of physical activity. Food fortification and awareness of available mineral rich local resources is essential to overcome this problem up to some extent. With this context millets are very important, as it contains high amount of minerals, amino acids and antioxidants. However, millets are still considered as the food for poor and traditional consumers because of non-availability of ready-to-use or ready-to-eat convenience food products and also the limited efforts made to diversify its food uses by application of traditional and contemporary food-processing methods.

Finger millet (Local name -Nagli) is usually used for preparation of flour, pudding, porridge and roti [1]. With the changes in scenario of utilization pattern of processed products and awareness of the consumers about the health benefits, finger millet has gained importance because of its functional components, such as slowly digestible starch and resistant starch [2], exceptionally rich in calcium (344 $\mathrm{mg} \%$ ) compared to all other cereals and an excellent plant source of natural iron $3.9 \mathrm{mg} \%$. [3]. It is a good source of carbohydrate, protein, dietary fibre and minerals [4], and have the unique property of slower digestibility [5]. Moreover the crop is productive in a wide range of environments and growing conditions. In spite of all these advantages, finger millet has been a neglected crop both at national as well as global levels due to number of causes. One of the major cause is its fortification and non -availability of recipes and compete with other fast food or ready to cook products.

Present work deals with standardization of finger millet recipes to enhance mineral content especially calcium and iron and analysis of marketed products to find out its nutritional potential.

\section{Collection and screening of Finger millet germplasm:}

\section{II. in Materials And Methods}

Landraces of Finger millet (Eleusine coracana (L.) Gaertn) were collected from the Western Ghats lies in Maharashtra. Locally it is called as Nagali or Nachani. Collected landraces and two cultivars Dapoli-1 and Dapolisafed were analyzed for their morphological characters [6] and mineral content [7]. Best 12 landraces contain higher amount of minerals especially calcium and iron were selected for recipes preparation (TABLE 3). 


\section{Standarization of receipee:}

Seven different recipes of finger millet were standardized viz. cookies, idli, dosa, laddu, cake, Papad and sheera. During preparation of recipe variety of modifications were done to maintain maximum amount of calcium and iron. Few were use of Jaggery instead of sugar, no baking powder or baking soda, use of dry fruits, milk and cardamom (elaichi), variation in temperature $\left(150{ }^{\circ} \mathrm{C}-2500^{\circ} \mathrm{C}\right.$ ) and duration of baking (For cake $180^{\circ} \mathrm{C}$ for 25 min. and for cookies $170^{\circ} \mathrm{C}$ for $15 \mathrm{~min}$.) .

3. Market survey:

Market survey was done to collect finger millet products such as Biscuits, Cookies, and Papad from different bakeries of Nashik city (Maharashtra) and nearby region. During survey information was gathered to understand the details of recipes.

4. Estimation of calcium and iron:

Mineral content of standardized recipes and marketed products were estimated by using ICP OES. (AOAC 2011.14). Instrument used MY15150010, Software version 7.200.7934.65269Firmware version3121(TABLE 1) 5. Organolaptic Test:

To check the acceptability of the consumer organoleptic testing was done by using standard protocol [8]. The sensory evaluation of the standardized recipes was done by the 50 people. Obtained data was processed to find out the acceptability index.

\section{Nagli laddu: Nagli flour +Jaggery +Ghee}

\section{Indentations and EQUATIONS}

Nagli flour was roasted and mixed with roasted peanuts and seasame. Sieved jaggery syrup was then added to this mixture along with the ghee. Later laddus were prepared out of the made mixture.

\section{Nagli Cookies: Nagli flour +Jaggery +Ghee + sprouted wheat flour.}

Finger millet cookies were prepared by mixing flour and sprouted wheat flour in 4:1 ratio. Jaggery was dissolved in milk. All ingredients were mixed together and cookies were made and baked on 170 degree for 15 $\min$.

\section{Nagli Sheera: Nagli Rava +Jaggery + Milk +Dry fruits}

Nagli rava and water were mixed into a paste. This mixture was heated in a thick-bottomed vessel on medium heat, stirring constantly. After 3 minutes, the powdered jaggery, cardamom powder and ghee were added. It was cooked for another 3 minutes till it become thick in consistency.

\section{Nagli Cake: Nagli rava + Butter milk + Jaggery + Dry Fruits + Elaichi}

Nagli rava and butter milk were mixed to make batter. In this jaggery, white butter and baker's yeast was added. A pinch of elaichi was added for flavor. This mixture was kept for fermentation for about 1 hour. After fermentation the cake was baked at 180 degree for about 20 minutes.

\section{Nagli Idli: Nagli Grain +Rice +Urad Dal.}

Rice, Nagli grains and urad dal was taken in 2:2:1 proportion and soaked for 6 hours separately. After 6 hours drain the water and grind it to a thick paste. Keep it aside for fermentation overnight. Salt is added to this batter and idli were prepared.

\section{Nagli Dosa: Nagliflour + Rice flour + Urad dal flour + Dry yeast + Jaggery}

Nagli four, Rice flour and urad dal flour was taken in 2:2:1 ratio and were mixed together .Dry yeast and Jaggery were added to this mixture. It was then fermented for 10 hours. Little salt was added to batter and dosa were made.

\section{Nagli Papad: Nagli Grains + Salt + Cumin seeds +Spice mix}

Nagli grains were soaked for 16 hours, and germinated for 48 hours. Germinated grains were dried in shed for 2 days and grind to make fine powder. Water was heated in vessel and sprouted nagli flour was added to it. Cumin seeds and spice mix were added. The mixture was continuously stirred till it became thick in consistency .Papad were made and dried in sun for 2 days.

IV. Figures and Tables

Table 1: Calibration Parameter

\begin{tabular}{|l|c|c|c|}
\hline Label(Wavelength nm) & $\begin{array}{c}\text { Minimum } \\
\text { Concentration }\end{array}$ & Maximum Concentration & Calibration Error \\
\hline $\mathrm{Ca}(393.63)$ & $0 \mathrm{mg} / \mathrm{kg}$ & $55 \mathrm{mg} / \mathrm{kg}$ & $15 \%$ \\
\hline $\mathrm{Ca}(422.67)$ & $0 \mathrm{mg} / \mathrm{kg}$ & $55 \mathrm{mg} / \mathrm{kg}$ & $15 \%$ \\
\hline $\mathrm{Fe}(238.20)$ & $0 \mathrm{mg} / \mathrm{kg}$ & $55 \mathrm{mg} / \mathrm{kg}$ & $15 \%$ \\
\hline
\end{tabular}

Table 2: Amount of minerals in standarised receipe and marked products

\begin{tabular}{|c|c|c|}
\hline Recipe And Marketed products & Calcium (mg/100gm) & Iron( mg/kg) \\
\hline Upma & 149.2 & 48.46 \\
\hline
\end{tabular}


Calcium and Iron Rich Recipes of Finger millet

\begin{tabular}{|l|l|l|}
\hline Sheera & 68.4 & 30.87 \\
\hline Cookies & 194.8 & 257.49 \\
\hline Dosa & 83.8 & 57.98 \\
\hline Idli & 40.27 & 26.12 \\
\hline Cake & 123.5 & 27.21 \\
\hline Laddu & 194.3 & 44.23 \\
\hline Papad & 227.2 & 52.09 \\
\hline Papad (Marketed) & $\mathbf{5 9 . 3 4}$ & $\mathbf{1 4 . 2}$ \\
\hline Biscuits(Marketed) & $\mathbf{5 1 . 8}$ & $\mathbf{5 8 . 1 1}$ \\
\hline Cookies (Marketed) & $\mathbf{4 5 . 5}$ & $\mathbf{3 4 . 2}$ \\
\hline
\end{tabular}

Table 3: Amount of minerals in control verities and landraces

\begin{tabular}{|l|l|l|}
\hline Control And Landraces & Calcium (mg/100gm) & Iron (mg/100gm) \\
\hline Dapoli- 1 & 290 & 11.2 \\
\hline DapoliSafed & 234 & 23.7 \\
\hline Vangni & 296.6 & 368.155 \\
\hline Hattipada-white & 304.2 & 53.513 \\
\hline Rajbari & 364.6 & 80.325 \\
\hline Kengpada & 244.6 & 424.1 .6 \\
\hline Hattipada-Red & 273.4 & 59.41 \\
\hline Pratabgad & 317 & 128.17 \\
\hline Manjdeja & 290.5 & 156.232 \\
\hline Jawle & 302.8 & 11.81 \\
\hline Kavthe & 317.1 & 29.664 \\
\hline Karanjali & 308.4 & 26.201 \\
\hline Kolhapur & 323.4 & 36.472 \\
\hline Jamneshpada & 260.1 & \\
\hline
\end{tabular}

Table 4: Summary of Sensory Evaluation

\begin{tabular}{|l|c|c|c|c|c|c|}
\hline \multicolumn{1}{|c|}{ Product } & Observation & Average & $\begin{array}{l}\text { Standard } \\
\text { Deviation }\end{array}$ & Min Score & Max Score & $\begin{array}{l}\text { Acceptability } \\
\text { Index }(\%)\end{array}$ \\
\hline Nagli Cookies & 50 & 9.43 & 0.92 & 7 & 10 & 86 \\
\hline Nagli Sheera & 50 & 8.69 & 1.61 & 3 & 10 & 80 \\
\hline Nagli Upma & 50 & 8.78 & 1.45 & 5 & 10 & 80 \\
\hline Nagli Laddu & 50 & 8.86 & 1.33 & 5 & 10 & 81 \\
\hline
\end{tabular}

\section{Conclusion}

All standardized recipes were prepared from the flour of 12 best landraces containing higher content of calcium and iron. Among seven recipes, cookies $(194.8 \mathrm{mg} / 100 \mathrm{gm})$ and Laddu $(194.5 \mathrm{mg} / 100 \mathrm{gm})$ retains maximum amount of calcium. Cookies were made by altering the duration and temperature of baking; it contains a good combination of calcium $(194.8 \mathrm{mg} / 100 \mathrm{gm})$ and iron $(257.49 \mathrm{mg} / \mathrm{kg})$. Baking temperature was $170^{\circ} \mathrm{C}$ for $15 \mathrm{~min}$; higher temperature during baking affected the content of calcium and iron. Incorporation of finger millet flour in the preparation of bakery products like biscuit, nankhatai (specific cookies), muffins and bread has been attempted and efforts are being made [9] to standardize the recipe and product quality. The use of millets in bakery products will not only superior in terms of fiber content, micronutrients but also create a good potential for millets to enter in the bakery world for series of value added products.

Cake is normally prepared with refined wheat flour, sweetening agent (sugar), binding agent, egg, fat and vanaspati, liquid flavour and some form of leavening agent such as yeast or baking powder. In our standardized recipe baker's yeast has used as leavening agent. Finger millet cakes retain a good amount of calcium $(123.5 \mathrm{mg} / 100 \mathrm{gm})$ and were made without using baking soda and baking powder. Sodium bicarbonate (baking soda) is generally well tolerated. However, a high dose shows side effects which include metabolic alkalosis, edema due to sodium overload, congestive heart failure, hyperosmolar syndrome, hypervolemic hypernatremia, and hypertension due to increased sodium[9]. In recent years finger millet has received attention and efforts are under way to provide it to consumers in convenient forms [10].

Traditional wheat flour and chickpea flour laddus are high in refined sugar and saturated fats but low in other important nutritional and functional ingredients. Laddus are popular as a snack. Therefore, they have high acceptability due to which improving on factors lacking in the traditional laddu was attempted in a scientific manner. Finger millet contains appreciable amounts of functional components concentrated in their seed coat [11]. In our recipe we have used only finger millet flour which helps to retain more amount of calcium $(194.3 \mathrm{mg} / 100 \mathrm{gm})$ and the addition of jaggery and peanut helps to retain more amount of iron $(44.3 \mathrm{mg} / \mathrm{kg})$ .These nutritious laddus can be promoted as a part of complementary feeding for children, adults and everyone in need of concentrated source of minerals in an acceptable form.[12] have formulated Composite flour laddu using a mix of cereals, sprouted legumes, malted millets, dairy ingredients, fruit, oil and jaggery and evaluated 
for particle size, colour, texture, nutritional, functional and sensory evaluation and compared with traditional wheat and chickpea flour laddus.

Fermented foods like Dosa and Idli are popular in many parts of India. These are very common as breakfast foods and even as the evening meals in southern part of the country. Finger millet is widely used as one of the ingredient for these kinds of fermented foods. It not only improves the taste but at the same time enriches the food value in terms of protein, calcium and fibre [13], [14], [15]. In our studies the Finger millet Idli and Dosa shows more amount of calcium and iron (TABLE 2). Out of these two Dosa retains more calcium $(83.8 \mathrm{mg} / 100 \mathrm{gm})$ and iron $(57.98 \mathrm{mg} / \mathrm{kg})$.

Mineral analysis of all five recipes reveal the retention of good amount calcium and iron (TABLE 2).Out of all the recipes, finger millet cookies shows maximum amount of calcium (194.8 $\mathrm{mg} / 100 \mathrm{gm})$ and iron $(257.49 \mathrm{mg} / \mathrm{kg})$. Cookies were made with only finger millet flour with little addition of sprouted wheat flour. Addition of jiggery instead of sugar helps to retain more amount of iron. Moreover changes in duration and temperature of baking affects the content of these two minerals. Research findings have revealed that substitution of $40 \%$ wheat flour with finger millet flour in baked products like cake and biscuits are possible [16], [17], [18] tried to explore the possibility of using seed coat matter (SCM) of finger millet in preparation of biscuits using the composite flour with comparable crisp texture, breaking strength (1480-1690 g), higher protein, dietary fibre and calcium contents compared to control biscuits .

The survey during collection of marketed products revealed that the biscuit available in market contains ammonia in it which is harmful to health and which reduces the amount of minerals. The process of making papad includes germination of finger millet to prepare malt and papad are made out of it. According to a report, addition of finger millet up to $60 \%$ in papad is possible and practiced in some parts of Karnataka [19]. In marketed papad they used to add more amount of baking soda for increasing size of papad. During standardization of papad recipe attempts were made to optimize the time of soaking and germination (16 hours soaking and 48 hours germination). Moreover no baking soda was added and preferably papad were roasted than frying. The amount calcium is highest in standardized papad $(227.2 \mathrm{mg} / 100 \mathrm{gm})$. Roasting process render the grain digestible, without the loss of nutritious components [20], [21]. Prepared millet papad (rolled, circular and thin sheets) by substituting $50 \%$ of mixture of black gram dhal flour and sago flour with finger millet flour and compared with black gram (Phaseolusmungo) dhal papad. The finger millet flour papad had higher sensory score of 4.7 on a five point hedonic scale and were rich in $\mathrm{Ca}(102 \mathrm{mg} \%$ in roasted and $109 \mathrm{mg} \%$ in fried) .In our studies the papad are made out of germinated finger millet grains (16 hours soaking and 48 hours germination) which were grind and sieved to 100 sq.cm mesh. These papad retains maximum amount of calcium $(227.2, \mathrm{~g} / 100 \mathrm{gm})$. The marketed products e.g. biscuits, papad contains less amount of calcium and iron might be because of ingredients used and the recipe process e.g. high temperature during baking, addition of baking powder and baking soda and others which impart features others than nutritional qualities. The sensory evaluation revealed that all standardized products are well accepted by people of all age group. The average rating for cookies was $9.43 \pm 0.92 \mathrm{SD}$, for laddus $8.86 \pm 1.33 \mathrm{SD}$ and for cake9.13 \pm 1.14 . The acceptability index was above $80 \%$ for all the products indicating that these products are highly acceptable (TABLE 4). Comparative analysis of standardize recipes with the marketed products revealed that these recipes are superior in terms of calcium and iron. The processing conditions and ingredients used in all recipes helps to maintain nutritional qualities and retention of calcium and iron contents. All the standardize recipes can be easily prepared and successfully used for supplementary feeding programme.

\section{Acknowledgements}

The authors thanks to Principal, H.P.T. Arts and R.Y.K. Science College, for providing all required facilities. One of the author (T.K) thanks Molana Azad National Fellowship (MANF) New Delhi, India for the award of Junior Research Fellowship. The authors are also thankful to CEO of Krishidoot Bio-herbals, Dr. R.V. Jagtap for providing the laboratory facilities to carry out work and for his kind support.

\section{REFERENCES}

[1] Chaturvedi, R. and S. Srivastava, 2008.Genotype variations in physical, nutritional and sensory quality of popped grains of amber and dark genotypes of finger millet.J. Food Sci. Technol., 45(5): 443-446.

[2] Wadikar, D.D., R.S. Premvalli, Y.S. Satyanarayanswamy and A.S. Bawa, 2007.Lipid profile in finger millet. J. Food Sci. Technol., 44(1): 79-81.

[3] Gopalan, C., B.V. Ramasastri and S.C. Balasubramanian, 2004.Nutritive value of Indian Foods. National Institute of Nutrition (NIN). Indian Council of Medical Research, Hyderabad, pp: 59-67.

[4] Sripriya, G., Usha, A., Chandra, T.S., 1997. Changes in carbohydrate, free amino acids, organic acids, phytate and $\mathrm{HCl}$ extractability of minerals during germination and fermentation of finger millet (Eleusine coracana). Food Chemistry 58(4), 345- 350 
[5] Geetha C, Parvathi P (1990). Hypoglycemic effect of millet incorporated breakfast items on selected noninsulin dependent diabetic patients. Indian J. Nutr. Dietetics, 27: 316-320

[6] Auti S.G; KaziTahsin; Ahire D.D. Morpho - agronomic diversity in Eleusine coracana (L.) Gaertn landraces from Maharashtra State (India).Journal of Scientific Agriculture, [S.1.], v. 1, p. 54-61, Jan 2017. ISSN 2184-0261.

[7] Tahsin Kazi, Auti S.G. Screening of higher mineral containing finger millet landraces from Maharashtra. International Journal of Food Science and Nutrition, Volume 2; Issue 3; May 2017; Page No. 21-25. ISSN: $2455-489$.

[8] Ghavidel, R.A. and Prakash, J. (2007), "The impact of germination and de-hulling on nutrients, antinutrients in vitro iron and calcium bioavailability and in vitro starch and protein digestibility of some legume seeds", LWT-Food Science and Technology, Vol. 40 No. 7, pp.1292-1299.

[9] Desai, A. D., S. S. Kulkarni, A. K. Sahu, R. C. Ranveerand P. B. Dandge. 2010. Effect of supplementation of malted ragi flour on the nutritional and sensorial quality characteristics of cake. Adv. J. Food Sci. Tech. 2(1):67-71.

[10] Malleshi NG (2003) Decorticated finger millet (Eleusine coracana). US Patent No: 2003/0185951

[11] Shahidi, F. and Chandrasekara, A. (2013), "Millet grain phenolics and their role in disease protectionandhealthpromotion: areview", JournalofFunctionalFoods, Vol.12No.3.doi: 10.1016/j.jff.2013.02.004.

[12] DipikaAgrahar-MurugkarAimanZaidiChetanGupta, (2016),"Quality evaluation of composite flour laddu containing sprouted and malted ingredients ", Nutrition \& Food Science, Vol. 46 Iss 4 pp. 476487

[13] Chavan JK and Kadam SS (1989).Nutritional improvement of cereals by fermentation. Critical Reviews in Food Science and Nutrition, 28(5): 349400.

[14] Maha AM Ali, Tinay AH and Abdalla AH (2003). Effect of fermentation on the in vitro protein digestibility of pearl millet. Food Chemistry, 80: 51-54.

[15] Verma V and Patel S (2013). Value added products from nutri-cereals: Finger millet (Eleusine coracana) Emirates Journal Food Agriculture, 25(3): 169-176; doi: 10.9755/ejfa.v25i3.10764.

[16] Begum JM, Vijayakumari, Begum S, Pandy A, Shivaleela H and Meenakumari (2003).Nutritional composition and sensory profile of baked products from finger millet.). In: Recent Trends in Millet Processing and Utilization, CCS HisarAgril. Univ., Hisar, India, pp: 82-87.

[17] Yenagi N, Joshi R, Byadgi S and Josna B (2013).A hand book for school children: Importance of Millets in Daily Diets for Food and Nutrition Security. University of Agricultural Sciences, Dharwad, India, pp. $1-24$.

[18] Kiranmai, M., Kumar, C.B.M. and Ibrahim, M. (2011), "Comparison of total flavanoid content of Azadirachtaindica root bark extracts prepared by different methods of extraction", ResearchJournalofPharmacology, BiologyandChemicalScience, Vol.2No.3, pp.254-261.

[19] Begum JM (2007). Refined processing and Products for commercial use and health benefits from finger millet. In: KrishneGowda KT and Seetharam A (Eds.), Food Uses of Small Millets and Avenues for Further Processing and Value Addition, Project Coordination Cell, All India Coordinated Small Millets Improvement Project, ICAR, UAS, GKVK, Banglore, India.

[20] Krantz ME, Panaari S, Colgate S (1983). - Sarbottanpitholl.a home prepared waeaning food for Nepal. Hoviprep monograph series no. 1. UNICEF/ US agency for international development. International Food and Nutrition Programme. p. 5

[21] Vidyavati H, Mustai Begum J, Vijayakumari J, Gokaki S and Shemshad Begum (2004).Utilization of finger millet in the preparation of papad.Journal of Food Science and Technology, 41(4): 379-382. 